\title{
FRAKSI ETANOL RIMPANG JERINGAU (Acorus calamus L.) SEBAGAI ANTIBAKTERI RERHADAP Staphylococcus aureus DAN Escherichia coli
}

\section{Ethanol Fraction of Jeringau Rhizomes (Acorus calamus L.) As Antibacterial Againts Staphylococcus aureus and Escherichia coli}

Pratika Viogenta, Nopiyansyah, Fitri

Program Studi Farmasi-Universitas Tulang Bawang Lampung

Email : pratikaviogenta@gmail.com

085289588824

\begin{abstract}
Acorus calamus $L$. (jeringau) rhizomes are one of the medicinal plants used as traditional medicine in Indonesia. This plant were used as an antibacterial. The purpose of this research were to prove the inhibition jeringau rhizome on the selected microorganisme including two bacterial trains Staphylococcus aureus and Escherichia coli. The rhizomes of jeringau were extracted with maceration method using ethanol $70 \%$ and fractionation process using solvent $v / v$ (ethanol, $n$-hexane and chloroform). The antibacterial activity used the cup plate method with the concentration $20 \%, 40 \%, 60 \%, 80 \%$, and $100 \%$, positive control using ampicillin and negative control using aquades. The test were continved by determining the minimum inhibitor concentration (MIC). Research was obtained zone diameters of $0 \mathrm{~mm}$ (negative control), $35.37 \mathrm{~mm}$ (positive control), $23.33 \mathrm{~mm}$ (concentration 20\%), $25.52 \mathrm{~mm}$ (40\%), $27.11 \mathrm{~mm}$ (60\%), $30.09 \mathrm{~mm}$ (80\%), and $33.16 \mathrm{~mm}$ (100\%) against Staphylococcus aureus. Inhibitory zone diameters $0 \mathrm{~mm}$ negative control, $36.68 \mathrm{~mm}$ positive control, 22.53 $\mathrm{mm}$ (concentration 20\%), $25.85 \mathrm{~mm}(40 \%), 28.08 \mathrm{~mm}$ (60\%), $29.73 \mathrm{~mm}(80 \%)$, and 32.21 $\mathrm{mm}(100 \%)$ against Escherichia coli. The minimum inhibitory concentration (MIC) value in both bacterial were $2 \%$. The results showed that all fraction concentrations could inhibit the growth of Staphylococcus aureus and Escherichia coli.
\end{abstract}

Keywords : Rhizome Jeringau, Staphylococcus aureus, Escherichia coli.

\section{Abstrak}

Rimpang jeringau (Acorus calamus L.) merupakan salah satu tanaman obat yang digunakan sebagai obat tradisional di Indonesia. Tanaman ini dimanfaatkan sebagai antibakteri. Tujuan dari penelitian ini adalah untuk membuktikan adanya daya hambat rimpang jeringau terhadap pertumbuhan bakteri Staphylococcus aureus dan Escherichia coli. Proses ekstraksi rimpang jeringau dilakukan dengan metode maserasi menggunakan penyari etanol $70 \%$ sementara proses fraksinasi menggunakan metode cair-cair dengan pelarut etanol, $\mathrm{n}$ heksan dan kloroform. Pengujian aktivitas antibakteri menggunakan metode sumuran dengan konsentrasi $20 \%, 40 \%, 60 \%, 80 \%$, dan 100\%, kontrol positif menggunakan ampisilin dan kontrol negatif menggunakan aquades. Pengujian dilanjutkan dengan menentukan Konsentrasi Hambat Minimun (KHM). Penelitian diperoleh zona hambat yang terbentuk terhadap Staphylococcus aureus dengan kontrol negatif $(0 \mathrm{~mm})$, kontrol positif $(35.37 \mathrm{~mm})$, konsentrasi 20\% (23.33 mm), 40\% (25.52 mm), 60\% (27.11 mm), 80\% (30.09 mm), dan $100 \%(33.16 \mathrm{~mm})$. Hasil diameter zona hambat yang terbentuk terhadap Escherichia coli kontrol negatif $(0 \mathrm{~mm})$, kontrol positif $(36.68 \mathrm{~mm})$, konsentrasi $20 \%(22.53 \mathrm{~mm}), 40 \%(25.85$ $\mathrm{mm}$ ), 60\% (28.08 mm), 80\% (29.73 mm), dan 100\% (32.21 mm). Nilai konsentrasi hambat minimum pada kedua bakteri sebesar $2 \%$. Hasil penelitian menunjukan bahwa semua 
konsentrasi fraksi dapat menghambat pertumbuhan Staphylococcus aureus dan Escherichia coli.

Kata kunci : Rimpang jeringau, Staphylococcus aureus, Escherichia coli.

\section{PENDAHULUAN}

Indonesia kaya akan berbagai jenis tanaman yang dapat dimanfaatkan sebagai obat tradisional. Diantaranya tanaman yang memiliki potensi untuk dikembangkan sebagai obat tradisional adalah rimpang jeringau (Acorus calamus L.). Secara tradisional, jeringau banyak digunakan sebagai obat untuk kulit dan sakit perut. Rimpang jeringau berguna sebagai spasmolitik, karminatif, dan berguna untuk sedasi, pencernaan, penenang, meningkatkan nafsu makan, tonik, antiinflamasi, meredakan hidung tersumbat, dan antiseptik [1].

Selama ini pengobatan yang biasa dilakukan untuk penyakit infeksi diatasi dengan menggunakan antibiotik. Penggunaan antibiotik yang berlebihan bisa membuat mikroba patogen menjadi resisten. Mikroba resisten ini penyebab utama kegagalan pengobatan infeksi. Oleh sebab itu untuk mengatasi hal tersebut maka perlu dicari alternatif pengobatan untuk mengatasi penyakit infeksi, salah satunya dengan pencarian senyawa aktif antibakteri yang terdapat pada tumbuhan jeringau [2].

Ekstrak rimpang jeringau diketahui memiliki efektivitas menghambat pertumbuhan bakteri Stahpylococcus aureus dan Escherichia coli. kandungan senyawa yang terdapat di ekstrak rimpang jeringa yaitu senyawa alkaloid, flavonoid, dan polifenol, yang memilliki potensi antibakteri [3].

Adanya kandungan senyawa metabolit sekunder yang memiliki makanisme untuk menghambat bakteri menjadi dasar dilakukannya ektraksi untuk menarik senyawa aktif dari dalam rimpang jeringau. Metode ekstraksi yang digunakan pada penelitian ini adalah metode maserasi yaitu dengan merendam simplisia kedalam pelarut yang sesuai. Pada penelitian ini menggunakan pelarut etanol $70 \%$ karena etanol bersifat universal yang dapat menarik senyawa aktif dengan sempurna [4].
Banyaknya senyawa dan pengotor yang terkandung dalam ekstrak etanolik rimpang jeringau menjadi dasar dilakukan tahan pemisahan senyawa tertarget dengan metode fraksinasi. Fraksinasi dengan prinsip perbedaan sifat partisi cair-cair dilakukan dengan tujuan untuk memisahkan senyawa aktif yang terkandung didalam ekstrak etanolik rimpang jeringau dengan prinsip perbedaan sifat kepolaransenyawa aktif. Sehingga, senyawa-senyawa yang terkandung didalam ekstrak saling terpisah ke dalam pelarut yang sifatnya sama dengan sifat senyawa aktif [5].

Tujuan pada penelitian ini untuk membuktikan aktivitas antibakteri dan memperoleh nilai konsentrasi fraksi etanol rimpang jeringau ( $A$. calamus L.) dalam menghambat pertumbuhan $S$. aureus dan E. coli.

\section{METODE PENELITIAN}

\section{Alat dan Bahan}

Alat yang digunakan alat-alat gelas, rotary evaporator, Bahan yang digunakan rimpang jeringau, biakan bakteri Escherichia coli, Staphylococcus aureus, ampisilin, media Nutrient Agar (NA) dan Nutrient Broth (NB), aquades $(\mathrm{H} 2 \mathrm{O})$, etanol $70 \%(\mathrm{C} 2 \mathrm{H} 6 \mathrm{O})$, kloroform $(\mathrm{CHCl} 3), \mathrm{n}$ -Heksan ( $\mathrm{CH} 3(\mathrm{CH} 2) 4 \mathrm{CH} 3)$, asam klorida ( $\mathrm{HCl} 2)$, kalium iodida (KI), raksa (II) klorida ( $\mathrm{HgCl} 2)$ dan besi klorida ( $\mathrm{FeCl} 3)$.

\section{Pembuatan Ekstrak dan Fraksi Rimpang Jeringau}

Sebanyak $4 \mathrm{~kg}$ rimpang dikeringkan. Ekstrak dibuat dengan merendam sampel sebanyak $400 \mathrm{gr}$ simplisia ke dalam etanol $70 \%$ dengan 6 kali remaserasi. Selanjutnya maserat diuapkan menggunakan rotary evaporator hingga diperoleh ekstrak kental. 
Ekstrak yang diperoleh difraksinasi dengan ditambahkan pelarut etanol dan $\mathrm{n}$-heksan dengan perbandingan 1:1 hingga didapat fraksi etanol dan fraksi n-heksan. Kemudian fraksi etanol difraksinasi kembali dengan penambahan pelarut kloroform dengan perbandingan 1:1 hingga didapat fraksi etanol dan kloroform. Fraksi etanol dipekatkan dengan menggunakan hotplate hingga mendapatkan fraksi etanol rimpang jeringau.

\section{Identifikasi Kimia Fraksi Etanol Rimpang Jeringau}

\section{a. Reaksi Identifikasi Alkaloid}

Fraksi etanol ekstrak rimpang jeringau sebanyak $3 \mathrm{ml}$ ditambahkan dengan $1 \mathrm{ml}$ asam klorida $(\mathrm{HCl}) 2 \mathrm{~N}$ dan ditambahkan $9 \mathrm{ml}$ aquades, dipanaskan di atas penangas air selama 2 menit, dinginkan dan saring. Tiga tetes filtrat dipindahkan pada kaca arloji dan ditambahkan pereaksi mayer. Bila terbentuk endapan berwarna coklat [6].

\section{b. Reaksi Identifikasi flavonoid}

Fraksi etanol ekstrak rimpang jeringau sebanyak $3 \mathrm{ml}$ dilarutkan didalam $5 \mathrm{ml}$ etanol, dipanaskan selama 5 menit, saring selanjutnya ditambahkan beberapa tetes $\mathrm{HCl}$ pekat dan $2 \mathrm{gr}$ serbuk $\mathrm{Mg}$, Bila berlihat warna hijau coklat menunjukkan adanya flavonoid [6].

\section{c. Reaksi Identifikasi Polifenol}

Fraksi etanol ekstrak rimpang jeringau sebanyak $3 \mathrm{ml}$ dilarutkan didalam $10 \mathrm{ml}$ aquades, dipanaskan kemudian disaring selanjutnya ditambahkan $\mathrm{FeCl} 3$ sebanyak 5 tetes. Bila terlihat warna hijau kehitaman atau biru tua menunjukan adanya polifenol [6].

\section{d. Reaksi Identifikasi Saponin}

Fraksi etanol ekstrak rimpang jeringau sebanyak $3 \mathrm{ml}$ ditambahkan $10 \mathrm{ml}$ aquades lalu dipanaskan air $50{ }^{\circ} \mathrm{C}$, dikocok selama 30 detik. Adanya busa stabil selama 10 menit setinggi $3 \mathrm{~cm}$ menandakan adanya saponin [6].

\section{Uji Daya Antibakteri}

Uji daya antibakteri dilakukan dengan menyiapkan cawan petri steril kemudian dituangkan $100 \mu \mathrm{L}$ suspensi bakteri lalu ditambahkan media NA kemudian dibiarkan memadat. Beberapa lubang dibuat pada agar nutrient dengan menggunakan blue tip dengan berdiameter $6 \mathrm{~mm}$. Lalu dimasukkan larutan uji kedalam lubang-lubang dengan masing-masing konsentrasi $(20 \%, 40 \%$, $60 \%, 80 \%, 100 \%$ ) dan antibiotik ampisilin sebagai kontrol (positif), aquades kontrol (negatif). Semua cawan petri diinkubasi dalam inkubator pada suhu $37^{\circ} \mathrm{C}$ selama 18 jam. Pengamatan dilakukan dengan mengukur zona hambat yang terbentuk disekeliling lubang dengan menggunakan jangka sorong.

\section{Uji KHM dan KBM}

Pengujian daya hambat fraksi rimpang jeringau akan disiapkan dengan beberapa tabung reaksi yang berisi $4,9 \mathrm{ml}$ NB yang mengandung larutan uji dengan konsentrasi terendah yang memberikan daya hambat pada uji daya antibakteri dan $0,1 \mathrm{ml}$ suspensi bakteri $S$. aureus dan $E$. coli Selain itu disiapkan 3 tabung reaksi sebagai kontrol, tabung pertama sebagai kontrol media yang berisi $5 \mathrm{ml}$ media NB, tabung kedua berisi media NB 4,8 $\mathrm{ml}+0,2$ $\mathrm{ml}$ larutan uji sebagai kontrol larutan uji dan tabung ketiga sebagai kontrol Bakteri yang berisi $4,9 \mathrm{ml}$ media $\mathrm{NB}+0,1 \mathrm{ml}$ suspensi bakteri.

Masing-masing tabung diinkubasi selama 18 jam. Pengamatan dilakukan dengan membandingkan kekeruhan media. Tabung reaksi yang jernih dibiakan kembali pada media tanpa penambahan mikroba uji ataupun agen mikroba, dan diinkubasi selama 18 jam. Media yang terlihat tidak ada pertumbuhan mikroba ditetapkan sebagai konsentrasi bunuh minimum atau KBM.

\section{Analisis Data}

Data hasil uji daya antibakteri dianalisis menggunakan two way ANOVA dengan uji 
lanjut tukey dan LSD menggunakan software SPSS versi 22.

\section{HASIL DAN PEMBAHASAN}

\section{Ekstraksi dan Fraksinasi Rimpang Jeringau}

Pada penelitian ini digunakan rimpang jeringau segar sebanyak $4 \mathrm{~kg}$ kemudian dikeringkan sehingga menghasilkan $900 \mathrm{gr}$ simplisia. Pengambilan senyawa aktif yang terkandung di dalam rimpang jeringau dilakukan dengan metode maserasi. Metode ini termasuk dalam ekstraksi cara dingin yang dapat dlakukan tanpa menggunakan pemanasan sehingga kerusakan pada zat yang tidak tahan terhadap pemanasan dapat terhindari. Selain itu keuntungan lainnya adalah zat-zat dalam sel-sel simplisia akan tertarik sempurna dari pelarut yang sesuai. Maserat di rotary evaporator sehingga mendapatkan ekstrak kental sebanyak 150 gr. Kemudian dilakukan fraksinasi terhadap ekstrak dengan berbagai jenis pelarut dengan berbagai tingkat kepolarannya yaitu $\mathrm{n}$ - heksan (non polar), kloroform (semipolar), dan etanol (polar). Pelarut n-heksan dilagukan untuk menarik senyawa yang bersifar non polar, pelarut kloroform untuk menarik senyawa yang bersifat semipolar dan pelarut etanol untuk menarik senyawa polar. Penggunaan ketiga pelarut tersebut untuk mendapatkan senyawa yang benerbener murni. Fraksi yang digunakan dipenelitian ini adalah fraksi etanol. Fraksi yang didapat dipekatkan menggunakan hotplate dan menghasilkan $60 \mathrm{ml}$.

\section{Uji fitokimia fraksi rimpang jeringau}

Uji fitokimia dilakukan untuk mengetahui senyawa metabolit sekunder yang terdapat pada pada fraksi rimpang jeringau.

Hasil dari uji skrining fitokimia fraksi etanol rimpang jeringau yang dilakukan dengan uji warna ini adalah positif terdapat senyawa alkaloid, flavonoid dan saponin.
Tabel 1. Hasil identifikasi fraksi etanol rimpang jeringau

\begin{tabular}{c|c|c|c}
\hline Analisis & MetodeUji & Hasil & simpulan \\
\hline Alkaloid & $\begin{array}{c}\text { Aquades }+\mathrm{HCl} \\
+ \text { Mayer }\end{array}$ & $\begin{array}{c}\text { Endapan } \\
\text { Coklat }\end{array}$ & + \\
\hline Flavanoid & $\begin{array}{c}\text { Etanol }+\mathrm{HCl}+ \\
\mathrm{Mg}\end{array}$ & $\begin{array}{c}\text { Hijau } \\
\text { Coklat }\end{array}$ & + \\
\hline Polifenol & $\begin{array}{c}\text { Aquades }+ \\
\mathrm{FeCl}_{3}\end{array}$ & $\begin{array}{c}\text { Hijau } \\
\text { Kehitaman }\end{array}$ & + \\
\hline Saponin & $\begin{array}{c}\text { Sampel+ } \\
\text { Aquades panas } \\
\text { dikocok }\end{array}$ & $\begin{array}{c}\text { Terbentuk } \\
\text { Busa }\end{array}$ & - \\
\hline
\end{tabular}

Keterangan

$(+)$ : Mengandung metabolit sekunder

$(-)$ : tidak mengandung metabolit Sekunder

\section{Identifikasi Alkaloid}

Terbentuk endapan pada mayer berarti dalam fraksi etanol rimpang jeringau terdapat alkaloid. Tujuan penambahan $\mathrm{HCl}$ adalah karena alkaloid bersifat basa sehingga biasanya difraksi dengan pelarut yang bersifat asam.

Hasil positif alkaloid pada uji mayer ditandai dengan terbentuknya endapan coklat. Endapan tersebut adalah komplek kalium- alkaloid. Pada pembuatan pereaksi mayer, larutan merkurium (III) klorida ditambah kalium iodida akan bereaksi membentuk endapan coklat merkurium(III) iodida. Jika kalium iodida yang ditambahkan berlebih maka akan terbentuk kalium tetraiodomerkurat(II).

Alkaloid mengandung atom nitrogen yang mempunyai pasangan elektron bebas sehingga dapat digunakan untuk membentuk ikatan kovalen koordinat dengan ion logam. Pada uji alkaloid dengan pereaksi Mayer, diperkirakan nitrogen pada alkaloid akan bereaksi dengan ion logam $\mathrm{K}^{+}$dari kalium tetraiodomerkurat(II) membentuk kompleks kalium-alkaloid dengan endapan coklat. 


\section{Identifikasi Flavonoid}

Hasil identifikasi flavanoid magnesium dan asam klorida bereaksi membentuk gelembung-gelembung yang merupakan gas $\mathrm{H}_{2}$, sedangkan logam $\mathrm{Mg}$ dan $\mathrm{HCl}$ pekat berfungsi untuk mereduksi inti benzopiron yang terdapat pada struktur flavanoid sehingga terbentuk perubahan warna menjadi merah atau jingga. Jika dalam suatu ekstrak tumbuhan terdapat senyawa flavanoid akan terbentuk garam flavilium saat penambahan $\mathrm{Mg}$ dan $\mathrm{HCl}$ yang berwarna hijau coklat.

\section{Identifikasi Polifenol}

Hasil identifikasi polifenol dilakukan dengan menambahkan larutan $\mathrm{FeCl}_{3}$ terhadap sampel. Sampel yang mengandung polifenol akan membentuk senyawa kompleks $\mathrm{Fe}^{3+}$ polifenol dengan ikatan koordinasi dengan terjadinya perubahan warna menjadi hijau kehitaman atau hijau kecoklatan. Hal ini terjadi karena atom $\mathrm{O}$ pada polifenol dapat mendonorkan pasangan elektron bebasnya ke $\mathrm{Fe}^{3+}$ yang memiliki orbital kosong membentuk ikatan kovalen koordinat untuk menjadi suatu senyawa kompleks.

Manfaat senyawa alkaloid, flavonoid dan polifenol terhadap rimpang jeringau yaitu berfungsi untuk mengikat protein, menguatkan susunan kapiler, menjaga pertumbuhan normal, sebagai pigmen warna, pengaruh infeksi dan kerusakan. Manfaat senyawa alkaloid, flavonoid dan polifenol yang terdapat pada rimpang jeringau dibidang kefarmasian yaitu dapat sebagai antibakteri, antijamur, antivirus, antikanker, antidiabetes dan antiinflamasi.

\section{Bakteri Staphylococcus aureus}

Hasil uji daya antibakteri fraksi etanol rimpang jeringau terhadap bakteri Staphylococcus aureus menunjukan adanya zona hambat, dengan ditandai adanya zona bening disekitar lubang sumuran pada masing-masing konsentrasi ( $20 \%, 40 \%$, $60 \%, 80 \%, 100 \%$ ) dan pada kontrol positif, tetapi pada kontrol negatif tidak menunjukkan zona bening.

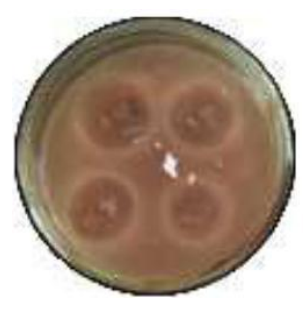

A.

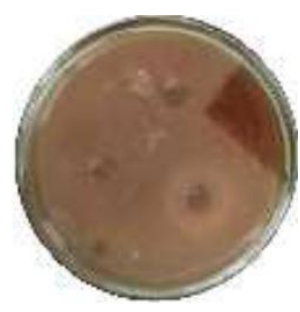

B.
Gambar 1. (A) Hasil uji daya antibakteri fraksi etanol rimpang jeringau dengan konsentrasi $40 \%, 60 \%, 80 \%$, dan $100 \%$ terhadap bakteri Staphylococcus aureus. (B) Hasil 20\%, kontrol positif, dan kontrol negatif.

Hasil penelitian uji daya antibakteri terhadap S.aureus menunjukkan bahwa fraksi etanol daun ungu mempunyai zona hambat terkecil pada konsentrasi $20 \%$ dengan diameter zona hambat $23,33 \mathrm{~mm}$ dan zona hambat terbesar pada konsentrasi $100 \%$ dengan diameter zona hambat $33,16 \mathrm{~mm}$.

\section{Bakteri Escherichia coli}

Hasil uji daya antibakteri fraksi etanol rimpang jeringau terhadap bakteri Escherichia coli menunjukan adanya zona hambat, dengan ditandai adanya zona bening disekitar lubang sumuran pada masing-masing konsentrasi ( $20 \%, 40 \%$, $60 \%, 80 \%, 100 \%$ ) dan pada kontrol positif, tetapi pada kontrol negatif tidak menunjukkan zona bening.

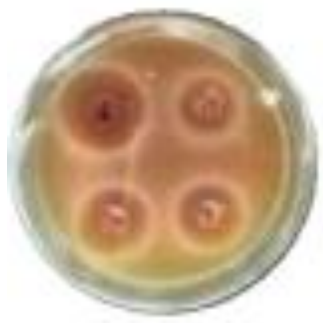

A.

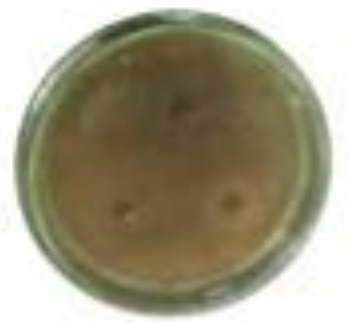

B.
Gambar 2. (A) Hasil uji daya antibakteri fraksi etanol rimpang jeringau dengan konsentrasi $40 \%, 60 \%$, $80 \%$, dan $100 \%$ terhadap bakteri Escherichia coli. (B) Hasil 20\%, kontrol positif, dan kontrol negatif.

Hasil penelitian uji daya antibakteri terhadap $E$. coli menunjukkan bahwa fraksi 
etanol rimpang jeringau mempunyai zona hambat terkecil pada konsentrasi $20 \%$ dengan diameter zona hambat $22,53 \mathrm{~mm}$ dan zona hambat terbesar pada konsentrasi $100 \%$ dengan diameter zona hambat 31,21 $\mathrm{mm}$.

Dapat diketahui bahwa fraksi etanol rimpang jeringau mempunyai keefektifan dalam menghambat bakteri terhadap bakteri $S$. aureus dan $E$. coli dengan masing-masing konsentrasi memiliki zona hambat pertumbuhan yang kuat dan pada konsentrasi $100 \%$ menunjukkan hambatan pertumbuhan yang sangat kuat [6].

Tabel 2. Rata-rata diameter zona hambat fraksi etanol rimpang jeringau terhadap bakteri $S$. aureus dan E. coli

\begin{tabular}{c|c|c}
\hline \multirow{2}{*}{ Perlakuan } & \multicolumn{2}{|c}{ Zona Hambat (mm) } \\
\cline { 2 - 3 } & S. aureus & E. coli \\
\hline Kontrol (-) & $0^{\mathrm{a}}$ & $0^{\mathrm{a}}$ \\
\hline Kontrol (+) & $35.37^{\mathrm{b}}$ & $36.68^{\mathrm{b}}$ \\
\hline $20 \%$ & $23.33^{\mathrm{c}}$ & $22.53^{\mathrm{c}}$ \\
\hline $40 \%$ & $25.25^{\mathrm{d}}$ & $25.85^{\mathrm{d}}$ \\
\hline $60 \%$ & $27.11^{\mathrm{e}}$ & $28.08^{\mathrm{e}}$ \\
\hline $80 \%$ & $30.76^{\mathrm{f}}$ & $29.73^{\mathrm{f}}$ \\
\hline $100 \%$ & $33.16^{\mathrm{g}}$ & $31.21^{\mathrm{g}}$ \\
\hline
\end{tabular}

Hal ini menunjukan bahwa semakin tinggi konsentrasi fraksi etanol rimpang jeringau maka diameter zona hambat semakin besar sedangkan pada kontrol positif zona hambat yang dihasil kan mempunyai respon hambatan pertumbuhan yang sangat kuat.

Perbedaan aktivitas antibakteri yang dihasilkan oleh kedua bakteri tersebut disebabkan karena fraksi etanol dapat melarutkan senyawa aktif antibakteri yang bersifat polar, sehingga fraksi etanol rimpang jeringau memiliki potensi lebih untuk dijadikan sebagai antibakteri alami. Keberadaan senyawa alkaloid, flavonoid dan polifenol yang terdapat pada fraksi rimpang jeringau tersebut memiliki peranan penting sebagai senyawa antibakteri [6].

\section{Uji KHM dan KBM}

Uji KHM dan KBM ini dilakukan untuk mengetahui kadar berapa fraksi etanol rimpang jeringau dapat menghambat pertumbuhan bakteri. Uji konsentrasi hambat minimum (KHM) dan konsentrasi bunuh minimum (KBM) dilakukan pada beberapa konsentrasi yaitu dari konsentrasi 1\% - 10\%. Dapat dilihat pada Tabel 3.

Tabel 3. Hasil uji konsentrasi hambat minimum

\begin{tabular}{c|c|c|c}
\hline No & Konsetrasi & S. aureus & E. coli \\
\hline 1 & $10 \%$ & - & - \\
\hline 2 & $9 \%$ & - & - \\
\hline 3 & $8 \%$ & - & - \\
\hline 4 & $7 \%$ & - & - \\
\hline 5 & $6 \%$ & - & - \\
\hline 6 & $5 \%$ & - & - \\
\hline 7 & $4 \%$ & - & - \\
\hline 8 & $3 \%$ & - & + \\
\hline 9 & $2 \%$ & - & - \\
\hline 10 & $1 \%$ & + & - \\
\hline 11 & $\begin{array}{l}\text { Kontrol } \\
\text { Media }\end{array}$ & - & $\begin{array}{c}\text { Kontrol } \\
\text { larutan uji }\end{array}$ \\
\hline 13 & $\begin{array}{l}\text { Kontrol } \\
\text { bakteri }\end{array}$ & - & + \\
\hline
\end{tabular}

Berdasarkan hasil uji daya antibakteri, maka penentuan KHM atau KBM dilakukan pada konsentrasi $1 \%-10 \%$. Hasil dilusi cair menunjukkan bahwa pada konsentrasi $2 \%$ tidak terdapat pertumbuhan bakteri kemudian konsentrasi yang tidak terdapat pertumbuhan bakteri tersebut digoreskan ke media NA untuk menentukan KHM atau KBM. Hasil dari uji KHM atau KBM bahwa fraksi etanol rimpang jeringau pada bakteri $S$. aureus dan $E$. coli yaitu $2 \%$ yang bersifat bakteristatik. 


\section{KESIMPULAN}

Berdasarkan hasil penelitian yang telah dilakukan dapat disimpulkan bahwa fraksi etanol rimpang jeringau dapat menghambat pertumbuhan bakteri $S$. aureus dan $E$. coli dengan semua konsentrasi yang tergolong respon sangat kuat dan bersprektrum luas, dengan konsentrasi hambat minimum sebesar $2 \%$.

\section{DAFTAR PUSTAKA}

[1] Rita WS. 2017. The Essential Oil Contents Of Jeringau (Acorus Calamus L.) Rhizomes and Their Antifungal Activity Against Candida albicans. Journal Of Health Scinces and Medicine UNUD journals. 1(1):33-38

[2] Shenvi, S., Vinod, Hegde, R., Kush, A., Reddy, G. C. 2011. A unique water soluble formulation of $B$-asarone from sweet flag (Acorus calamus L.) and its in vitro activity against some fungal plant pathogens. Journal of Medicinal Plants Research. pp.5132- 5137.

[3] Anisah. 2014. Aktivitas antibakteri ekstrak rimpang jeringau terhadap Staphylococcus aureus dan Escherichia coli. protobiont. 3(3):1

[4] Direktorat Jendral Pengawasan Obat dan Makanan. Pedoman teknologi formulasi sediaan berbasis ekstrak. Vol II. Jakarta: Dapertemen Kesehatan Republik Indonesia; 2013.

[5] Ningsih D.R. Zusfahair. Kartika D. 2016. Identifikasi senyawa metabolit sekunder serta uji aktivitas ekstrak daun sirsak sebagai antibakteri. purwokerto Jur Kim FMIPA Univ Jendral Soedirman. 104.

[6] Wiwik Indriyati. 2014. Uji Aktivitas Antibakteri Ekstrak dan Fraksi Daun Bambu Kuning (Bambusa vulgaris Schrad) Terhadap Sthaphylococcus aureus dan Escherichia coli 


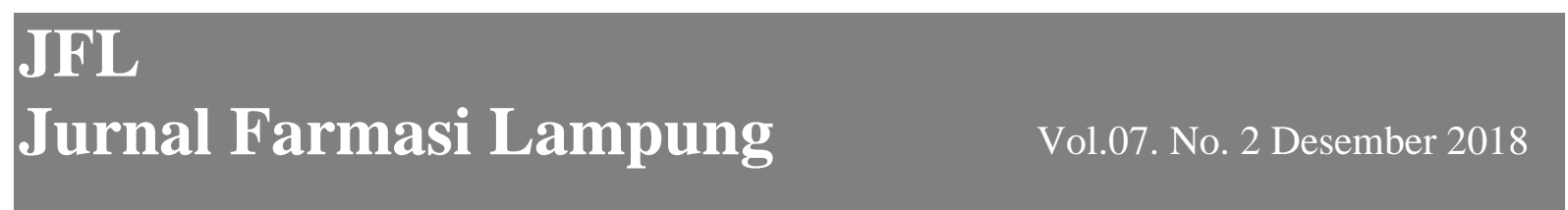

